\title{
Oor roeping en arbeid in Protestantse etiek
}

D J Smit

(Universiteit Stellenbosch)

\section{ABSTRACT \\ On calling and labour in Protestant ethics.}

Several popular and influential theological and ethical studies have recently been published relating to the notion of vocatio (calling) and the role of labour and work. Many of them focus again on the importance of this traditional link between (spiritual) calling and (everyday) work in Christian, and particularly Protestant ethical thought since Luther. This paper argues that the nature of this link has, however, radically changed since Luther's time, and that it can be very confusing if contemporary ethical reflection does not distinguish carefully between Luther's own ideas concerning calling (part 2), later developments within Protestantism (parts 3 and 4), and contemporary ethical challenges (parts 5 and 6). Only by making such careful distinctions, taking into account that human labour no longer plays the same role in modern societies which it played during Luther's time or during later forms of Protestantism, can one develop adequate categories to reflect on the relation between church and work today.

Daar verskyn deesdae baie teologiese en etiese publikasies rondom die temas van roeping en arbeid. Vergelyk hier onder andere die tekenende werke van outeurs soos William H Lazareth (1979), Richard H Luecke (1979), Jaroslav Pelikan (1985), Miroslav Volf (1991), Reinhard Hütter (1993), 'n aantal werke uit 1998 onder andere die van Gary D Badcock, Zygmunt Bauman, William C Placher, ook R Paul Stevens (1999), Gilbert C Meilaender (2000), en laastens ook die twee boeke van Johan Botha en John E Hare (2001) oor die onderwerp. ' $n$ Verdere belangrike bydrae tot die gesprek is die werk van Douglas J Schuurman (1998a 1998b \& 2001), 'n gesaghebbende op hierdie gebied wat 'n paar jaar gelede besoek aan Suid-Afrika gebring het, en binnekort ' $n$ gesaghebbende monografie hieroor behoort te publiseer.

Wanneer ' $n$ mens aandagtig na die werk op hierdie terrein kyk, is daar grootskaalse verwarring te bespeur, omdat die betekenisse wat aan roeping toegeken word oor die hele spektrum wissel. Verder word etiese vraagstukke wat elk hulle eie benadering verg dikwels vermeng, soos byvoorbeeld arbeidsetiek, ekonomiese etiek en roepingsetiek, asook die kerk se betrokkenheid by die arbeidswêreld, deurdat dit basiese onderskeidings moontlik maak, sowel tussen hulle tye en moderne samelewings, as tussen verskillende velde binne kontemporêre etiese besinning self. 
' $n$ Kort historiese terugblik na die bydrae wat die Protestantisme, en heel spesifiek Luther, en na hom die Lutherse tradisie tot hierdie vraagkompleks gemaak het, mag dalk sinvolle nadenke en gesprek rondom hierdie onderwerp bevorder.

\section{GELOOF EN LEWE?}

Die Christelike kerk, veral die Protestantisme, het "n lang - alhoewel ingewikkelde en dikwels omstrede - geskiedenis met "werk," in die populêre sin van "betaalde arbeid".

Hierdie noue verband en tegelyktydige spanning tussen "bid" en "werk" - tussen ora en labora, soos dit dikwels in die kerkgeskiedenis genoem is - is natuurlik ' $n$ onderdeel van die groter, meer omvattende spanningsverhouding tussen geloof en lewe, tussen vroomheid en alledaagse lewe, tussen geestelike lewe en gewone menslike bestaan, tussen herskepping en skepping.

Aan die een kant is daar klaarblyklik innige verbande, verweefdheid, samehang. Geloof het alles te make met die lewe, vroomheid alles met alledaagse lewe, geestelike lewe alles met ons gewone menslike bestaan, God se herskepping met God se goeie skepping. Weinig Christene sal dit ontken.

Aan die ander kant is daar egter ook voor-die-hand-liggende spanninge, selfs konflikte. Geloof is iets anders as net die normale lewe. Vroomheid wil juis die alledaagsheid stempel, beïnvloed, dikwels transformeer. Die eise en aansprake, die prioriteite en belange van die geestelike lewe staan meermale radikaal téénoor die eise en aansprake, die prioriteite en belange van die gewoonheid en die vleeslikheid. Die nuutheid van die herskepping staan dikwels haaks met die oudheid van wat aan sonde onderworpe is, en aan die verbygaan. Ook dít sal die meeste Christene bely.

Dit is duidelik waarom hierdie komplekse verhouding tussen geloof en lewe in die geskiedenis van die Christelike kerk dikwels na vore gekom het in vrae rondom "bid" en "werk". Hoe beïnvloed hierdie twee mekaar? Hoe belangrik is hulle regtig, onderskeidelik? Is een ondergeskik, diensbaar aan die ander?

Is "bid" Christen-mense se eintlike werk, sodat dit beter sou wees, selfs ideaal sou wees, as ons so veel as moontlik daarmee besig is, soveel tyd as moontlik daaraan afstaan, terwyl ons “dagtaak" eintlik net ' $n$ sleur is, iets wat ons ongelukkig moet doen om te kan oorleef, maar nie iets waarin God regtig geïnteresserd is nie? Is hemelse, geestelike take en sake die eintlike wat - werklik, vir God - saak maak?

Of geld die omgekeerde dalk? Is "bid” juis 'n manier om krag en wysheid te ontvang vir ons alledaagse lewe en take? Is die gevaar dalk dat 
ons so met hemelse sake besig kan wees dat ons nutteloos is vir die aarde, wat die eintlike plek is waar God ons wil gebruik?

Ten diepste is die vraag dus: wat wil God regtig hê dat ons moet wees en doen? Waarmee behoort ons besig te wees? Wat het - uiteindelik"ewigheidswaarde"?

Op talle maniere het hierdie spanning na vore gekom in die Christelike lewe, en in die alledaagse lewens van Christen-mense. Binne verskeie Christelike tradisies is oor jare, ja, eeue heen veel aandag gegee aan hierdie verhouding tussen bid en werk, tussen geloof en lewe.

\section{ROEPING}

Binne die Protestantisme het hierdie - tegelyk intieme en problematiese verhouding onder andere skerp na vore gekom in die heel besondere manier waarop oor "roeping" gepraat is.

\subsection{Nuwe Testament}

In die Nuwe Testament word "roeping" - dit wil sê die Griekse terme wat met "roeping" of aanverwante uitdrukkings vertaal word - natuurlik nie in verband gebring met "werk" in die moderne sin van betaalde arbeid, van ons dagtake, nie.

Die feit dat mense sekere werke gedoen het, word wel as ' $n$ soort vanselfsprekendheid aanvaar. Paulus self is trots op die feit dat hy ' $n$ tentmaker was, wat daardeur homself relatief onafhanklik van die gemeentes kon hou, waardeur sy apostoliese vryheid en vrymoedigheid bevorder is. En by geleentheid moedig hy die vroeë Christene aan om aan te hou werk. Hulle moes nie op grond van hulle verwagting van die nabye wederkoms ledig sit en wag vir dié dag nie. Hulle moes vir hulleself sorg, en ook nog iets oorhou om die armes mee te versorg.

Hierdie verwysings word egter nêrens met "roeping" in verband gebring nie. Geeneen word aangemoedig om hulle dagtake of lewensarbeid as roeping van Godsweë te sien nie. ' $n$ Sogenaamde "teologie van werk" kan 'n mens eintlik nie uit die Nuwe Testament aflei nie. Daar word eenvoudig nie genoeg daaroor gesê nie.

Die enigste moontlike uitsondering sou dalk 1 Korintiërs 7:17-24 kon wees. Daar word woorde wat van die stam "geroepe” (van kaleo) gevorm is nie minder nie as tien maal gebruik. Die gelowiges word opgeroep om te bly in die "roeping" waarin hulle was toe hulle "geroep" is. Of hulle besnede of onbesnede was toe hulle "geroep" is, of slawe of vrymense, is om "t ewe. Elkeen moet bly in die "roeping” waarin hulle geroep is en God daarin dien 
(verse 17, 20, 24). Klaarblyklik bedoel Paulus dit egter nie op wat ons vandag "werk" sou noem nie, maar eerder op iets soos "toestand", "omstandighede" of "situasie”. Só vertaal die Afrikaanse Bybel (1983) dit dan ook - in die gees van talle huidige vertalings - met "omstandighede" ("life" en "state" in die Revised Standard Version).

In die algemeen sou 'n mens miskien opsommend kon sê dat die Nuwe Testament daarvan uitgaan dat die onderskeide in stand, status of posisie tussen mense (soos slaaf of vrymens) deur die evangelie radikaal gerelativeer word. Dít in sigself bepaal nie wie deur God geroep en gered word of binne die kerk 'n plek vind nie. Verskillende soorte arbeid word in die algemeen geëer as maniere waarop die naaste gedien kan word, en, as dit met gebed en toewyding gepaard gaan, ook die Here. Dié arbeid is egter nie self die roeping van Godsweë nie, maar vorm hoogstens die ruimte en oomblik, die plek en tyd waar gelowiges geroep word tot redding, tot geloof, tot diens aan die naaste en aan die Here.

\subsection{Middeleeuse Christendom}

Tot met die tyd van Luther - dit wil sê dwarsdeur die Middeleeuse Christendom - was "roeping" inderdaad ook 'n toenemend belangrike saak, maar is dit meesal gesien as ' $n$ geestelike roeping, as die roeping om ' $n$ gelowige te wees.

Met verloop van tyd is dit selfs geïnstitusionaliseer, en het roeping al hoe meer ' $n$ tegniese uitdrukking geword vir ' $n$ uitgaan uit die wêreldse lewe in die amptelike, geestelike lewe binne die instituut of instelling van een van die geestelike ordes, byvoorbeeld in die kloosterlewe.

Om ' $n$ roeping te ontvang, of aan ' $n$ roeping gehoorsaam te wees, het dus letterlik begin beteken om die gewone, normale lewe agter te laat en oor te gaan na ' $n$ afgesonderde, toegewyde lewe as geestelike. Dikwels het dit gepaard gegaan met eedswering en totale en lewenslange toewyding aan die ideale van die betrokke orde en klooster. Die geestelike roeping was om volgens hierdie geestelike riglyne (consilia), soos gehoorsaamheid, kuisheid, of armoede, te lewe, terwyl gewone gelowiges in die alledaagse lewe slegs hoef te leef volgens die voorskrifte (praecepta) wat vir almal geld.

Kortom, daar was 'n duidelike onderskeid tussen geestelikes met ' $\mathrm{n}$ roeping en gewone gelowiges of leke sonder ' $\mathrm{n}$ roeping. In die laatMiddeleeuse Wes-Europese samelewings, veral in die stede, wat toenemend belangrik begin word, vind mens dus dat die lewe georden word volgens ' $n$ verskeidenheid van beroepe en stande (op Latyn onderskei tussen ordo, ministerium, professio, officium). Mense het aanvaar dat hierdie soort verdelinge met die natuur gegee is, so hoort, en Godgewil is.

Stand en arbeid kry dus meermale ' $n$ soort morele en godsdienstige 
waarde. Alle soorte arbeid word gerespekteer as integraal nodig vir die welwese van die gemeenskap, maar, te midde van al hierdie stande en beroepe is daar ook diegene wat ' $n$ "roeping” van God ontvang het, ' $n$ geestelike roeping, tot diens in die kerklike instituut, in een of ander vorm.

\subsection{Luther}

Met Luther kom daar egter radikale verskuiwinge in hierdie verband. En merkwaardig genoeg doen hy dit juis aan die hand van 1 Korintiërs 7:20.

In sy Septemberbibel van 1522 vertaal hy dié woorde so dat elkeen moet bly in die "roeping" (Ruf) waarin hulle geroep is, en later dieselfde jaar, in sy Kirchenpostille, vertaal hy dit selfs met "beroep" (beruf). Van toe af gebruik hy die uitdrukking "roeping” konsekwent op hierdie manier. Teen 1534, as hy Jesus Sirag 11:21ev vertaal, formuleer hy byvoorbeeld: Bly in God se Woord en oefen jou daarin, en volhard in jou beroep, ... Vertrou op God en bly in jou beroep". Dis nog merkwaardiger, aangesien die twee Griekse woorde wat hy hier uit die LXX vertaal (ergon en ponos) niks met die "geroep wees" (kalein) van Korintiërs te make het nie.

' $n$ Mens verstaan hierdie motief by Luther net as gesien word hoe dit saamhang met sy klem op die algemene priesterskap van alle gelowiges.

Die onderskeid tussen geestelikes en leke wil hy radikaal kritiseer en laat verval. Dis die duiwel - sê hy, op sy tipiese krasse manier - wat mense wil wysmaak dat hulle God beter kan dien deur uit die normale, alledaagse lewe te tree, nie te trou nie, en ' $n$ bestaan in geestelike afsondering in die kerk of klooster te gaan leef. Nee, God roep nie sommige nie, maar almal. Nie slegs sommige is priesters nie, maar almal. En God roep nie uit die wêreld uit nie, maar in die wêreld in, om daar vir God te leef. Dit beteken dat dit wesenlik vir gehoorsaamheid aan dié roeping is dat gelowiges sal bly in die posisie, die omstandighede, die situasie, ja, die roeping, die beroep, die arbeid, waarin hulle reeds staan. Nie dié wat in geestelike diens staan, dien God beter nie. Nee, álle diens bied geleentheid tot geestelike diens.

Dié ingrypende verskuiwing in opvatting oor wat “roeping” beteken, sou die Christendom sedertdien radikaal beïnvloed. Binne die Protestantisme sou hierdie ontwikkelinge net verder en verder deurgetrek word, wat tot diepgrypende vrae en baie skerp kritiek sou lei.

Dis daarom dalk nuttig om eers nog fyner te luister na hoe Luther self presies hieroor gedink het en wat hy wou sê.

* Hy aanvaar grootliks, soos sy tydgenote, die vanselfsprekendhede van die lewe van sy dag as normaal. Sy denke oor dié sake is in geen opsig nuut of radikaal nie. Hy gaan eenvoudig, soos almal, uit van die bestaan van vorsteISSN 1609-9982 = VERBUM ET ECCLESIA JRG 23(2) 2002 
state, stadjies, dorpe, en landelike lewe, soos wat hy dit geken het. Ook die bekende sieninge van sy dag oor die "verdelinge van verpligtinge" (die distributio officiorum, volgens ordo, status, officium) neem hy oor. Die gestaltes en verpligtinge van sowel die openbare lewe - in ons taal: die politiek - en die arbeids- en handelslewe - in ons taal: die ekonomie, letterlik: die huishouding - neem hy eenvoudig oor.

* Die beslissende skuif wat hy maak is om hierdie openbare en ekonomiese gestaltes en verpligtinge te sien as die uiterlike roeping waartoe God gelowiges, alle gelowiges, roep.

Soos sy tydgenote onderskei hy ook tussen 'n geestelike roeping (die vocatio spiritualis) en ' $\mathrm{n}$ uitwendige roeping (die vocatio externa). Na sý mening kom albei hierdie roepinge egter na álle gelowiges, as priesters, en nié net na sommige nie. Dit is daarby ook nie twee verskillende roepinge nie, maar kom sáám, as één roeping (die generalis vocatio), omdat dit die mens is, die persoon, wat deur God geroep word met hierdie dubbele roeping: die onmiddellike, geestelike roeping (die immediata vocatio), om te glo en jou te laat doop, en die bemiddelde, wêreldse roeping (die mediata vocatio), om God en jou naaste te dien in jou stand en arbeid.

Dié twee aansprake van God op ons, op alle gelowiges, kan wel onderskei, maar nie geskei word nie. Mense ontvang nie òf een òf die ander nie. Die twee kom saam as die één woord tot ons, deurdat God op ons as mense, konkreet, waar en wie en wat ons is, beslag lê deur sy roeping.

* Die verrassende hieraan is klaarblyklik die feit dat hy die konkrete situasie van gelowiges, hulle politieke (openbare) en ekonomiese (huishoudelike) posisies, pligte en status, insluit as integrale deel van die roeping van Godsweë.

Vir sy tydgenote moes dit ' $n$ bevrydende antwoord gebied het op eksistensiële vrae waarmee hulle geworstel het oor wat God werklik van hulle verlang.

Van twee kante af is die relevansie van hulle alledaagse lewe naamlik op dié tydstip verbreid in twyfel getrek. Aan die een kant was daar naamlik 'n oormaat van geestelikes wat hulle by ordes aangesluit het om God te dien. Daarby was daar egter ook die talle sogenaamde Schwärmer-bewegings wat in die naam van die Gees mense teen allerlei alledaagse beroepe gewaarsku het en verwarring in die openbare lewe gesaai het. Albei hierdie tendense het gewone, gelowige mense laat wonder oor wat God eintlik van hulle verlang. Dit is daarom te begrype dat hierdie oortuigings vir talle mense ' $n$ weg uit hulle vrae gewys het. Dit was skielik nie langer vir hulle nodig om die normale lewe te verlaat ten einde God se roeping te volg en Hom te dien nie.

* Deur gelowig deel te neem aan hulle stand en arbeid - het Luther geleer 486

OOR ROEPING EN ARBEID 
neem hulle deel aan God se voortgaande skepping. Deur dié samewerking (cooperatio) behaag dit God om te werk. So word mense diensknegte van God en medewerkers, instrumente van God, waarmee God sy werk in die wêreld bereik, as die eintlike Een wat déúr mense heen werk (die causa efficiens). Deur die boere melk God die koeie, leer Luther.

* Beroepsarbeid is dus gehoorsaamheid aan God se wil. Dit moet nie gedoen word ter wille van aansien (status, klas, of eer) nie, en ook nie ter wille van wins (persoonlike voordeel) nie. Nóg openbare of politieke, nóg ekonomiese voordeel moet nagestreef word. Die doel is nie om van een stand $n a$ ' $n$ ander te beweeg, of van een ekonomiese klas na ' $n$ ander een nie. Almal is nodig, almal is ewe waardig.

* Dis begryplik waarom gehoorsaamheid aan God se wil en getrouheid in die alledaagse arbeid in die samelewing die twee groot deugde sou word wat in die ontwakende Protestantse werksetiek op die voorgrond sou staan as dié twee sake wat ten alle koste nagejaag moet word.

* Natuurlik was die konkrete arbeidsituasies en -verhoudinge egter nog totaal anders as wat dit vandag in moderne ekonomieë die geval is. Alhoewel dit toe reeds - met die uitgang van die Middeleeue - steeds meer kompleks begin raak het, en vroeëre huishoudingsekonomieë toenemend begin plek maak het vir ruilhandel op die stadsmark, het dit tog nog tot ' $n$ baie groot mate berus op redelik direkte en persoonlike gee en neem.

Dáárom was dit vir Luther moontlik om te argumenteer dat hierdie daaglikse beroep of arbeid beleef kon en moes word as vrye en vreugdevolle naastediens. Die konkrete, sigbare naastes met wie mense in hulle alledaagse arbeid te doen gekry het, was almal mense wat mekaar - met hulle dienste en produkte - nodig gehad het. Wat dus ook al die (openbare, politiese) stand of (ekonomiese) werk of beroep was, kon gelowiges dit beleef as direkte en persoonlike diens aan konkrete naastes. Skoenmakers het die mense geken wat hulle skoene gedra het, en daagliks met hulle saamgeleef. Bakkers het geweet wie die mense is wat hulle broodjies eet, en wat hulle lewensomstandighede was. Van onderwysers tot vorste was almal volkome geïntegreer met die samelewing waarbinne en die mense onder wie hulle werksaam was.

* Om dié rede kon Luther dan ook daarvan uitgaan dat liefde, direkte en persoonlike naasteliefde, die diepste motief agter die gehoorsame en getroue alledaagse arbeid was.

Dié dialektiek - tussen tegelyk volkome vry én almal se slaaf - wat sy bekende en invloedryke geskrif Oor die vryheid van ' $n$ Christenmens sou 
kenmerk, het ook op hierdie terrein gegeld. In volkome vryheid kon gelowiges hulle uitgiet in hulle arbeid, omdat hulle daardeur hulle naastes in liefde tot diens was.

* Daaruit vloei weer die vreugde wat sulke stands- en beroepsarbeid moes kenmerk. Dit was die blydskap van vrye mense wat in gehoorsaamheid aan God hulle konkrete naastes kon dien, ongeag in welke stand of beroep hulle hulle bevind het.

* Ten alle koste moes hulle die duiwelse versoeking weerstaan wat die medewerking met God en die diens aan die naaste wou laat omslaan in die drang om vir jouself te werk, om jou stand of beroep te sien as geleenthede wat jy tot jou eie voordeel moes gebruik.

* Die tipies Protestantse vlyt of fluksheid - wat volgens baie waarnemers binne die Gereformeerde tradisie, vanweë ander godsdienstige motiewe, selfs nog sterker en meer karakteristiek sou word - vloei asof vanself uit hierdie soort denke voort. Harde en volhardende werk - vir God en naaste - is nodig, omdat dit die nodige gevolge, vrug, resultate oplewer, omdat dit met die verlangde sukses bekroon word, as die doelwit bereik is.

Sukses of beloning is egter bloot die resultaat van hierdie ywerige inspanning, nooit die dryfkrag of motivering nie. Presies so is verbetering van jou eie lewensituasie - hetsy polities (stand) of ekonomies (beroep) - ook nie die dryfkrag nie; inteendeel, by Luther val alle klem juis op die bly-indie-stand-en-beroep-waarin-Gods-roeping-of-aanspraak-tot-jou-kom.

Sosiale mobiliteit, om voortdurend opwaarts te klim op die leer van sukses, rykdom of eer, word volledig afgewys as diaboliese versoeking. Dit staan radikaal teenoor gehoorsame en liefdevolle diens. Eenvoud en soberheid kenmerk die lewe vanuit die roeping. Toegewyde pligvervulling in die gegewene word die hartstuk van die Protestantse arbeidsetiek.

\subsection{Samevattend}

Samevattend kan ' $n$ mens sê dat die ingrypende aard van hierdie verskuiwing vanaf die Middeleeue moeilik oorskat kan word.

Daar ontstaan 'n nuwe waardering vir die sogenaamde vita activa, die aktiewe lewe, die alledaagse, praktiese, konkrete lewe in die wêreld. Die geestelike lewe bestaan nie net in die meditatiewe, afgesonderde kloosterlewe nie - hoe sleutel-belangrik die innerlike, die persoonlike omgang met God, die lewe van meditasie en gebed ook al mag wees, maar juis in die gehoorsame en getroue ag gee op die konkrete roeping van God in die alledaagsheid, die hier en die nou.

\section{BEROEP}

In die geskiedenis van die Protestantisme sou verdere, ingrypende 488

OOR ROEPING EN ARBEID 
verskuiwinge egter algaande plaasvind. Dit is nie nodig om die hele verhaal weer hier voor die gees te roep nie. Enkele bekende aksente kan hoogstens onderstreep word.

Een baie belangrike ontwikkeling sou wees dat die uiterlike roeping wat Luther so verrassend ingesluit het as integrale deel van die één roeping toenemend losgemaak sou word van die geestelike roeping - wat vir hom wesenlik deel was van dié roeping - en verselfstandig sou word as die enigste en eintlik roeping. Die vocatio externa sou al hoe belangriker word en die vocatio spiritualis al hoe meer na die agtergrond verdring. Die aktiewe lewe word - vir baie mense - die eintlike en die enigste lewe.

Betekenisveranderinge in die term "beroep" - wat Luther self reeds begin gebruik het - sou hierin 'n simboliese rol speel. Dit sou alhoemeer so word dat Protestante sou begin dink hulle beroep ís hulle roeping. Dalk kan ' $n$ mens, skerp gestel, sê: Hulle word nie meer geroep om as Christene in hulle beroep te staan nie, maar hulle word as Christene geroep om in hulle beroep te staan.

Hierdie tipies Lutherse beroepsleer sou die kernstuk van die nuwe politieke etiek word in die patriargale wêreld van die evangeliese vorstedomme in die eerste dekades na die Reformasie. Reeds Melanchton self neem dit volledig oor in die Confessio Augustana (1530), in die artikel wat handel oor die burgerlike samelewing (De rebus civilibus). Toenemend word dit nou algemeen om te praat van "beroep en stand" (ordo, as ekonomiese aanduiding) en "beroep en amp" (officium, as politieke aanduiding). Die gelowiges se beroep is eintlik geleë in hulle "stand" en “amp".

In die populêre bewussyn val die klem al hoe meer op hierdie uiterlike, wêreldse beroep waarin gelowiges gehoorsaam en getrou moet wees.

\section{NUWE TENDENSE}

Verskeie tendense begin nou - vir die eerste maal - ontwikkel. Dit sou in later tye feitlik vanselfsprekend word, asof mense maar altyd so gedink het.

* Só word die innerlike roeping van God al hoe meer gesien as natuurlike, aangebore vaardighede, vermoëns of talente wat mense sou ontvang het. Jou natuurlike aanleg leer jou wat jou innerlike roeping is, en daarom ook watter uiterlike beroep jy dus behoort na te volg. En omdat dit natuurlik is, "van nature” gegee is, word dié aanleg geïnterpreteer as roeping van God Self.

* Hieruit word - vir die eerste maal - die moderne konsep van beroepskeuses gebore. Nie langer hoef gelowiges te bly in die roeping - stand of arbeid waarbinne hulle geroep word nie, maar hulle volg juis die Skeppergod se ISSN 1609-9982 = VERBUM ET ECCLESIA JRG 23(2) 2002 
roepstem deur op grond van hulle eie talente en aanleg in vryheid te besluit wat hulle graag wil word en doen.

* In die tweede helfte van die negentiende eeu sou - in verskillende tale hierdie opvattinge so algemeen posvat dat dit begin lei tot nuwe maniere om hierdie soort terme te gebruik, soos wat dit tipies sou bly tot in moderne samelewings.

Die idees van "roeping" (vocatio, "call/calling") en "beroep" (professio, "profession, work, job”) word radikaal geskei. Ironies genoeg word eersgenoemde, met godsdienstige bowetone, van nou af deur gewone mense weer feitlik uitsluitlik net in geestelike, religieuse of teologiese sin gebruik, indien hulle dit hoegenaamd ooit wel nog gebruik - byna weer soos in die tyd van die Middeleeue. Dit hoort slegs nog in kerklike en godsdienstige taal. Laasgenoemde word, onder die invloed van ingrypende prosesse van sekularisasie, die algemeen gangbare uitdrukking vir betaalde werk.

* Die gesekulariseerde, idealistiese oorblyfsel van die vroeëre geestelike roeping (vocatio spiritualis) is nou die voorstelling van ' $n$ innerlike neiging of geneigdheid, ' $n$ innerlike drang, begeerte of strewe om ' $n$ sekere soort werk "te gaan doen", om 'n sekere "iets te word". In hierdie sekulêre idee van "geroepe voel tot" word die vroeëre idee van "n Goddelike roeping feitlik gesensualiseer, as behoefte, begeerte of drang opgeneem.

* Hierdie nuwe sekulêr-idealistiese beroepsleer is - soos die vroeëre Lutherse leer - steeds sterk eties of moreel van aard. Uit die invloedryke beroepslere van mense soos Goethe, Wilhelm von Humboldt en veral Fichte, blyk dit maar al te duidelik.

Op ' $n$ rasionele wyse word die behoeftes van ' $n$ bepaalde samelewing geïnterpreteer in terme van die beroepe wat nodig is vir die goeie, ordelike burgerlike lewe in dié samelewing. Spesifieke beroepe of professies byvoorbeeld regsgeleerdes, medici, onderwysers - word as noodsaaklik geag. Die talente, vaardighede, aanleg of vermoëns wat dié professies benodig word beskryf. Van burgers word verwag om hulleself te ondersoek, hulle eie belangstellings, aanleg en talente vas te stel, en te vra vir welke van hierdie professies hulle aangelê is.

Die kombinasie van (objektiewe) geleentheid en (subjektiewe) aanleg of belangstelling word dan as pligte gesien - 'n sekulêre variasie van die vroeëre Goddelike vocatio. Mense is verplig om hulle talente ywerig te gebruik in diens van die samelewing. So word dié rasionele en sekulêre beroepsleer ten diepste ' $n$ sedeleer, ' $n$ rigoristiese pligte-etiek. 
* Die tradisionele - direkte, konkrete, persoonlike - naastediens word nou sekulêr geïnterpreteer - diens aan, nuttigheid in terme van die samelewing self, die geluk en welsyn van die geheel, die common good, die sisteem van algemene harmonie, orde en voorspoed.

* Vanuit die al meer invloedryke ekonomiese perspektief gesien, word dié sekulêre pligte-etiek, via die mark, die verantwoordelikheid om onpersoonlike diens te lewer aan die gemeenskaplike ekonomiese sisteem, wat uiteindelik - volgens Adam Smith se onsigbare hand-teorie - wel almal se beste belang sal dien.

* Dit beteken dat eie - veral ekonomiese - prestasie, sukses, voordeel, wins, op sekulêre wyse geïnterpreteer word as in die beste belang van die anonieme geheel. Sukses en prestasie, eie wins en persoonlike voordeel word die morele kriteria waaraan die gehoorsaamheid en die bydrae van mense gemeet word in die nuwe, gesekulariseerde sedeleer, geskoei op die sleutelrol van beroep, professie, en betaalde werk.

* In die plek van die statiese samelewingsbeeld van die vroeë Protestantisme - waarin stand en beroep, oorerflikheid en hiërargiese bevoorregting of benadeling feitlik onveranderlike gegewenhede gevorm het - word die klem nou geplaas op individuele keuse-vryheid, insluitende vryheid ten opsigte van beroeps- en loopbaankeuse en lewensontplooiing volgens innerlike drif, natuurlike talent en aangeleerde professionele vaardighede.

* Agter hierdie rasionele plig-etiek skuil duidelik 'n sterk emansipatoriese wil, 'n drang om bevryding, die begeerte om nié te bly in die stand en beroep waarin jy ' $n$ roeping ontvang het om daar 'n persoonlike God en die konkrete naaste te dien nie, maar om juis jouself te dien, deur, indien enigsins moontlik, steeds meer sukses en wins te behaal in (sosiale) stand en (ekonomiese) beroep, en deur dié voortdurende opwaartse mobiliteit (vermoedelik) jou God-gegewe talente te ontwikkel (indien jy verkies om so daaroor te dink) en indirek die gemeenskaplike belang te dien (indien jy verkies om so daaroor te dink).

* As al hierdie tendense tesáme beskou word, is die resultaat duidelik en bekend. Die vroeë Protestantse roepingsetiek is nie alleen gesekulariseer en geradikaliseer tot die welbekende - en berugte - Protestantse beroepsetiek nie, maar op 'n merkwaardige wyse eintlik punt vir punt in sy presiese teëdeel omgekeer.

* Dit is trouens geen wonder dat daar in Protestantse geledere - sedert byvoorbeeld Kant en Fichte - alhoemeer van die "religie van arbeid" gepraat sou word nie. Dit is asof arbeid, betaalde werk, professionele en 
beroepsarbeid, meermale en wyd verbreid ' $n$ surrogaat-godsdiens geword het, ' $\mathrm{n}$ vorm van afgodery, wat mense se lewens domineer, wat sy eie waardestelsel en morele kodes suggereer, en wat tot allerlei vorme van aanbidding voer, insluitende die bring van kosbare offers.

\section{KERK EN WERK?}

Teen hierdie agtergrond, geskilder aan die hand van verskuiwings in die siening van "roeping", is dit reeds sonder meer duidelik waarom die verhouding tussen kerk en betaalde werk - veral die Protestantisme - so intiem en tegelyk so kompleks en omstrede is.

Aan die een kant is dit vir Protestantse Christene feitlik onmoontlik om hulle terug te trek in ' $n$ lewensbeskouing waarin die wêreld-van-werk onbelangrik word, waarin hulle daaglikse arbeid niks met God te make het nie, waarin die eintlike geestelike en geloofslewe bestaan in 'n ontvlugting uit die alledaagse werklikheid na ' $n$ afgesonderde, geestelike sfeer en lewe. Aan die ander kant is dit vir baie Protestantse Christene toenemend onmoontlik om hulle volledig oor te gee aan die sekulêre pligte-etiek en die religie-van-die-arbeid, met die gedagte dat hulle op dié manier, deur hulleself te soek en te dien en voortdurend groter wins en roem na te jaag, eintlik besig is om God en hulle naaste te dien (vgl. Pelikan 1985; Hütter 1993; Meilaender 2000).

Aan die een kant weet die Christelike kerk dat hy nie kan swyg oor sy lidmate se alledaagse belewenis van die arbeidswêreld nie. Nie alleen maak hulle werk eenvoudig in die praktyk die grootste deel van baie mense se lewens uit nie, maar die wel en die wee van die werksituasie stempel ook die res van mense se lewens tot in die diepste dieptes: emosioneel en innerlik, in hulle huislike en familielewens, hulle vriendskappe, hulle waardes en prioriteite, hulle strewes en drome, hulle vrese en sorge, kortweg, in alle opsigte.

Meer fundamenteel nog, egter, is die oortuiging wat steeds in die kerk leef dat mense se alledaagse arbeidslewens alles met die diens aan God en die naaste te make het, dat dit op een of ander wyse in gehoorsaamheid aan die Here geleef en beleef behoort te word. Aan die ander kant is dit eenvoudig nie vir die Christelike kerk duidelik wat oor die implikasies van die evangelie vir die arbeidswêreld aan lidmate en mense verkondig en geleer behoort te word nie.

Dit is sonder meer duidelik dat die vroeë Protestantse sieninge van "roeping” georiënteer was aan 'n soort tyd en samelewing wat grootliks verby is, ten minste op baie plekke. Samelewings lyk en funksioneer net eenvoudig nie meer soos die wêreld waarin Luther geleef het en waarmee hy vertroud was nie. Dit het op duisende wyses meer kompleks geword, en 
daarmee saam ook - objektief - die plek wat arbeid in mense se lewens ineem, en - subjektief - die manier waarop mense hulle dagtaak beleef.

Vir dekades lank het die kerk probeer om hierdie visie tog nog waar te maak in die snel veranderende industriële wêreld, en dié opgaaf was al moeilik genoeg. Vandag sê mense egter al hoe meer dat ook die industriële tyd en kultuur in baie samelewings al iets van die verlede begin raak, en daarmee weer die maniere waarop mense hulle arbeid beleef in só ' $n$ wêreld.

Die nuwe soort lewenstyl in 'n globaliserende informasie-tydvak, en volgens sommige reeds ook ' $\mathrm{n}$ vólgende tydvak, naamlik een waarin ekologiese krisisse en verantwoordelikhede ons lewe gaan bepaal, bring eenvoudig mee dat die aard en plek van werk in mense se lewens radikaal verander.

Die kleindorpse, burgerlike lewe waaraan Luther se denke georiënteer het, is ligjare verwyder van die rekenaar-ekspert wat vanaf haar woonstel in New York reg rondom dié wêreld, en ongeag nag of dag, virtuele transaksies uitoefen met onsigbare kliënte vir nie-materiële betaalmiddele.

Dié soort gangbare definisie van "beroep" in die gebruiklike arbeidsetiek - te wete iets soos "die omvang van aktiwiteite, pligte en regte wat mense binne ' $n$ bepaalde sosiale orde voltyds en permanent beoefen en besit en waarmee hulle normaalweg hulle lewensonderhoud verwerf” - geld nie langer meer vir ' $n$ groeiende getal mense nie. Baie mense is werkloos (sien Luecke 1979; Bauman 1998). Baie werk nie meer binne 'n spesifieke sosiale orde alleen en vir die beswil en onder die beskerming van daardie orde alleen nie. Baie se regte word nie so duidelik aan hulle pligte gekoppel en beskerm nie. Baie beklee meer as een betrekking. Baie werk nie meer voltyds nie - en is in die res van hulle tyd ook op allerlei ander maniere besig. Baie doen hulle werk nie meer permanent en lewenslank nie, maar wissel herhaaldelik van werk, selfs radikaal wat betref die tipe werk wat hulle doen. Baie verdien nie regtig meer hulle volle lewensonderhoud uit hulle werk nie, maar het ander inkomstes of maniere van sosiale versorging.

\section{VRAAGKOMPLEKSE}

Talle vraagkomplekse dring hulle gevolglik as 't ware op wanneer die kerk hieroor probeer nadink. Vier daarvan kan by wyse van slagspreukagtige vrae hier bloot in herinnering geroep word:

\subsection{Werksetiek?}

Maak dit vandag - en in die lig van dié geskiedenis - nog enige sin om van ' $n$ werksetiek, 'n etiek van die arbeid, te praat? Wat sou 'n Christelike arbeidsetiek kon inhou, onder die radikaal veranderde omstandighede van ISSN 1609-9982 = VERBUM ET ECCLESIA JRG 23(2) 2002 
moderne samelewings?

* Werk die benadering wat so tipies was van die deugde-leer byvoorbeeld nog? Is dit korrek - en genoegsaam - om die bekende deugde van gehoorsaamheid en onderdanigheid ("asof vir die Here"), hardwerkendheid en vlyt, getrouheid en volharding, as die inhoud van 'n Christelike werksetiek te verkondig?

Of maak dié soort deugde dalk net goeie sin vir sommige groepe in die moderne ekonomie, te wete die relatief bevoorregtes, diegene met geleerdheid en opleiding, wat hulle in beroepe bevind waarin hulle emosionele bevrediging vind en wat hulle inderdaad kan sien as direkte diens aan God en die naaste?

Behoort daar dalk ander etiese kodes te geld vir ander groepe - sê byvoorbeeld vir die beamptedom of werknemers in die publieke sektor, vir direksies en direksielede, vir finansiers, vir handarbeiders, vir vakbondlede?

* Hiermee saam hang die problematiese soeke na sogenaamde gemeenskaplike waardes in die werkplek waarvan 'n mens vandag meermale hoor. Wat is dit presies, en wat sou dit kon wees? Is dit inderdaad die soeke na ' $n$ nuwe soort arbeidsetiek? Of is dit bloot die soeke na ' $n$ interne sosiale kontrak waaraan alle belanghebbende partye in ' $n$ bepaalde maatskappy of industrie hulle verbind, ten einde te probeer verseker dat alle betrokkenes se belange uiteindelik ten beste gedien sal word?

Is dit dus werklik ' $n$ etiese of morele kode - in enige tradisionele sin van dié terme - of is dit veeleer 'n oorlewingstrategie, 'n pragmatiese of funksionalistiese onderlinge akkoord, ondergeskik aan gemeenskaplike belange, waarin suksesvolle voortbestaan, genoegsame winsbejag, effektiewe kompetisie, bevredigende konflikbeslegting, kortom, kollektiewe selfsoeke, die uitgangspunt vorm (vgl. Schuurman 1998a; 1998b; 2001)?

Hoe noodsaaklik en sinvol sulke prosesse ook al is vir suksesvolle maatskappye en ondernemenings - sou dit die tradisionele rol van werksetiek kon vervang asof dit ' $n$ nuwe soort etiese kode sou wees? En nog meer spesifiek: Sou die Christelike etiek en die kerk enigsins ' $n$ bydrae kon lewer in sulke gesprekke, met die soort morele visies, waardes, deugde en handelinge wat tradisioneel ingebed sit in die Christelike selfverstaan?

* Dieselfde soort kritiese vrae geld aangaande die talle strewes van spesifieke beroepe of professies om morele kodes op te stel wat eie is aan hulle professie en wat die onderlinge akkoorde tot verantwoordelike gedrag moet beliggaam.

Wat presies sou professionele etiek kon beteken? Histories gesien het dié soort inisiatiewe juis ontwikkel as vrug van die gesekulariseerde 
roepingsetiek binne die Protestantisme. Natuurlik gaan dit veel verder terug, tot in die antieke en klassieke wortels van byvoorbeeld die Hippokratiese eed van gesondheidswerkers, maar binne tipies moderne samelewings sou hierdie benaderings geïntensiveer word as sekere professionele groepe as ' $t$ ware begin vra na die interne verpligtinge wat voortvloei uit die unieke aard van hulle eie professie. Soms bestaan 'n groot deel van dié gedragskode eintlik uit ongeskrewe, selfs onuitgesproke, dikwels elitistiese opvattinge wat eenvoudig gehuldig word. Slegs ' $n$ sekere soort mens word tot dié professie "toegelaat" en van hom (of haar, maar dikwels hom) word 'n sekere soort gedrag verwag, wat nie altyd net met morele kwessies te make het nie, maar meermale ook met lewenstyl, met etiket, met gebruike. Só word die beeld en die goeie naam van die professie beskerm en gekontinueer.

Meesal organiseer sulke professies - in talle moderne samelewings hulle dan ook tot professionele liggame, wat as politieke en juridiese entiteite funksioneer, met juridiese identiteit en mag, en hulle formuleer dan normaalweg ook professionele kodes, waarmee die integriteit en waardigheid van die professie verseker word. Met oortredinge van hierdie kode word selfs strafmaatreëls afdwingbaar. Heel dikwels is dit egter nie etiese kodes, in enige tegniese sin van die woord nie.

* 'n Belangrike variasie van hierdie soort benadering is wat vandag meermale besigheidsetiek genoem word. Dit dui op die talryke inisiatiewe om diegene wat werksaam is in die sogenaamde besigheidswêreld te help ondersteun om meer moreel, betroubaar en verantwoordelik om te gaan met hulle alledaagse aktiwiteite.

* Hierdie soort vrae word tans in Suid-Afrika besonder dringend met die huidige soeke om openbare korrupsie te bestry, onder andere deur ' $n$ reeks van nasionale Morele Berade, sedert 1998. Aanvanklik was dit godsdienstige en politieke leiers wat bymekaar gekom het vir konsultasies. Die bedoeling was om gemeenskaplike akkoorde op te stel, waartoe al die betrokke rolspelers hulle sou verbind. Van die begin af is die wens dan ook uitgespreek dat verteenwoordigers van die privaatsektor, sakelui, arbeiders, en besigheid hulle ook later met hierdie inisiatiewe en verklarings sou vereenselwig.

Die inhoud van die eerste dokumente kom eintlik net neer op ' $n$ persoonlike toewyding tot ideale van verantwoordelikheid, eerlikheid, en deursigtigheid. Die bedoeling is klaarblyklik dat korrupsie teengewerk moet word deur persoonlike verantwoordelikheidsgevoel by leiersfigure te probeer versterk.

- By al hierdie inisiatiewe - werksetiek, deugde-leer, gemeenskaplike ISSN 1609-9982 = VERBUM ET ECCLESIA JRG 23(2) 2002 
waardes in die werkplek, professionele etiek, besigheidsetiek, gesamentlike verklarings teen korrupsie - bly die vraag vir gelowiges en die kerk ten diepste egter staan of hierdie kodes werklik vanuit die evangelie - met sy eie logika, waardes, lewenstyl, roeping - gevul word.

Trouens, volgens baie kritiese waarnemers is die harde werklikheid dikwels miskien eerder die omgekeerde. Instede dat Christelike etiek, en ook die Christelike geloof en kerk, die wêreld van werk help beïnvloed en vorm - só glo hulle - beïnvloed en vorm die wêreld van werk miskien in die praktyk veel meer die etiek, die Christelike geloof en selfs die kerk.

Dikwels is die suigkrag van die religie van die arbeid veel sterker as wat ons sommer sou wou vermoed of erken. Meermale stempel die waardesisteme, die vanselfsprekendhede van die werk eerder die waardes en strewes van die kerk en die gelowiges, as omgekeerd.

\subsection{Ekonomiese etiek?}

Is dit om dié redes dalk vir die kerk en die Christelike etiek beter om eerder aandag te gee aan 'n tweede vraagkompleks, en na 'n ekonomiese etiek te vra? En meer spesifiek: word die kerklike belangstelling in werk, die Christelike betrokkenheid by die ekonomie, nie dalk hoofsaaklik gemotiveer deur die soeke na groter ekonomiese geregtigheid nie (vgl Lazareth 1979)?

Veral binne die Gereformeerde Protestantisme was dit inderdaad van vroeg af ' $n$ baie belangrike saak. Reeds vanaf Calvyn word hierdie besondere belangstelling in geregtigheid duidelik. Diep in die Gereformeerde drif skuil die verlange dat die samelewing, saam met die kerk en die lewe van die gelowiges, ge-reformeer moet word, wat beteken in groter gehoorsaamheid aan die Woord en die geopenbaarde wil van die Drie-enige God geleef sal word. In die openbare lewe verg dit dat die Christelike liefde gestaltes van geregtigheid moet aanneem - soos die bekende Gereformeerde teoloë Reinhold Niebuhr en Emil Brunner dit sou uitlê. En hierdie geregtigheid het binne die Gereformeerde visie - meesal ook die ekonomiese terrein ingesluit.

Dié besondere belangstelling van die Gereformeerde tradisie in die ekonomie is al op talle maniere deur sosiaal-historici beskryf, ontleed, en ook skerp gekritiseer.

' $n$ Mens hoef maar net die verhaal van die Wêreldbond van Gereformeerde Kerke sedert die laat negentiende eeu tot vandag te lees om diep onder die indruk te kom van hierdie merkwaardige passie by Gereformeerde kerke en gelowiges. Op die oomblik is dit steeds ' $n$ sentrale tema in dié kringe. By die Volle Vergadering in Debrecen (1997) is ' $n$ processus confessionis verklaar rondom ekonomiese en ekologiese geregtigheid in die wêreld. Dit hou in dat alle lidkerke opgeroep word om te 496

OOR ROEPING EN ARBEID 
bedink en te bely dat "ekonomie 'n saak van geloof" is - en wat die praktiese implikasies daarvan vir hulle eie lewens is.

Binne hierdie soek na "ekonomiese geregtigheid" kom 'n magdom temas aan die orde. In ekumeniese kringe word die aandag veral gevestig op die negatiewe kante van die teenswoordige globalisering van die ekonomie, met al die verwoestende en lewensbedreigende gevolge daarvan, insluitende die marginalisering en uitsluiting van groot dele en talle groepe van die wêreld.

In Suid-Afrikaanse kerke self kom daar eweneens talle sake ter sprake onder die sambreel van ekonomiese geregtigheid: die profetiese rol en openbare getuienis van die kerk; die kerk se houding teenoor en betrokkenheid by die regering se RDP en GEAR; beleidsvrae rondom restitusie, grondhervorming, regstellende aksie; konkrete optrede rondom werkloosheid; plaaslike, streeks- en gemeentelike projekte om armoede te bestry en by te dra tot die verbetering van die lewenslot van die armes, hetsy deur ontwikkeling of deur bevryding; en talle meer.

\subsection{Die kerk in die industrie?}

Ten nouste hiermee verwant is 'n derde vraagkompleks, te wete die talle vrae na die inhoud van die kerk se getuienis, die kerk se verkondiging, die kerk se bediening, rondom die wêreld van werk. Op ' $n$ baie spesifieke manier was dié vrae tradisioneel ter sprake ten opsigte van die kerk se sogenaamde bediening binne die industriële wêreld.

Histories was dit naamlik vir die kerk in talle samelewings, sedert die aanbreek van die industriële tydvak, van groot belang om binne die industriële lewe, as 't ware op die fabrieksvloer, aanwesig te wees.

Die redes waarom hierdie presensie nodig was, was egter deurgaans uiteenlopend, kompleks en selfs omstrede. En die aard van die kerklike betrokkenheid aldaar, die inhoud en doel van die industriële kerklike bediening, eweneens. Antwoorde op die vrae waarom die kerk in die industrie moet werk en wat die kerk daar behoort te doen, kan op 'n wye spektrum gerangskik word.

Op baie plekke is die "fabriek" - as simbool van die toe opkomende industriële ekonomie - gesien as blote werksterrein, as nog 'n plek, en wel ' $n$ belangrike een, om kerk te wees. Op dié lewensterrein - soos in skole, op kampusse, in hospitale, tronke en militêre basisse - kon talle mense deur die kerk bereik word wat dalk nie meer langs die tradisionele weë van die gemeentelike bediening ingetrek en bedien kon word nie. Die kerk het dus eenvoudig agter die mense aan gegaan en getrag om die groeiende werksmag 
te bereik en te bedien waar hulle die grootste deel van hulle tyd deurgebring het.

Die aard van die kerklike betrokkenheid en bediening in die werkplek het in sulke gevalle egter maar min verskil, indien enigsins, van die gewone kerklike aktiwiteite. Bidure is gehou, die Woord is bedien deur prediking, getuienis, Bybelstudie en die verspreiding van literatuur, en pastorale sorg en ondersteuning is verleen na aanleiding van die behoeftes en probleme waarmee die werkers na die kerk se verteenwoordigers sou kom.

Op talle ander plekke sou die kerk in die "fabriek" egter gou onder druk kom om die aard van sy betrokkenheid en sy teenwoordigheid ingrypend te wysig. Ook dié druk sou uiteenlopende vorme aanneem, soos wat dit van die kerk verwag is om volledig nuttig, diensbaar, te word aan die industriële kragte self.

Dikwels sou dit daarop neerkom dat die kerk se teenwoordigheid onder die werkers deur die eienaars geduld, en selfs moontlik gemaak en finansieel ondersteun sou word, sodat hulle sou funksioneer as ' $n$ vorm van pastorale noodhulp om die werkers onder hulle moeilike omstandighede tevrede te hou, en selfs beter gemotiveerd. Dikwels sou dit daarop neerkom dat die kerk sou kant kies en sou begin optree as kampvegter in die stryd van die werkers om beter lone, pakkette, versorging en werksomstandighede.

Vanselfsprekend was - en is - daar tussen hierdie pole op die spektrum ' $n$ wye verskeidenheid van moontlike vorme van aanwesigheid en bediening in die werkplek moontlik. Tot vandag toe worstel kerke in lande met sterk industriële ekonomieë steeds met hierdie soort vrae. Prakties kan dit dalk saamgebundel word in die vraag: Waarmee behoort die kerk vandag besig te wees in sy industriële bediening (sien Botha 2001)?

\subsection{Gelowiges en hul dagtaak?}

' $n$ Vierde stel vrae het te make met die praktiese vraag hoe gelowiges vandag nog hulle dagtaak beleef en hoe hulle as gelowiges daaroor dink. Ervaar hulle dit steeds as Goddelike, geestelike roeping? In welke sin (vgl Placher 1998; Stevens 1999)?

Hoe beleef hulle dan situasies van werkloosheid, wat so tipies is van moderne ekonomieë? Beleef hulle dit dan as roepingloosheid, as betekenisloosheid, uiteindelik dalk as waardeloosheid? En ten nouste verwant hieraan: hoe beleef en gebruik gelowiges hul vrye tyd? Wat is die verhoudinge tussen kerklike betrokkenheid, dagtaak, en vrye tyd? Wat is die prioriteite? Wat bied die diepste troos, sin, vreugde? En hoe beleef gelowiges die druk wat hul werksomstandighede en -vereistes dikwels op hulle familielewe en hulle persoonlike lewe plaas - die stres, die bekommernis en 
besorgdheid, die vrese?

Hoe beleef hulle die vanselfsprekendhede wat die werkswêreld op duisende maniere suggereer - die belangrikheid van prestasie en sukses, wins en voorspoed, steeds hoër lewenstandaarde en steeds meer besittings, kompetisie en selfhandhawing - as aansprake op hulle eie integriteit as gelowiges?

Kortweg, hoe praat die kerk met sy eie lidmate oor werk - in liturgie en prediking, in pastoraat en getuienis, in kategese en meningsvorming, in gesprekke oor moraal en lewe?

Dit kan ' $\mathrm{n}$ mens byna nie verbaas dat die Protestantse idee van "roeping" in talle kerke algeheel verlore geraak het nie. Baie gelowiges sien nie meer hulle dagtaak, hulle "betaalde werk", óf selfs hulle familie- en burgerlike verantwoordelikhede, as roepings van Godsweë nie. Die taal van "roeping” word waarskynlik in talle Protestantse kerke nie meer gebruik nie.

Trouens, indien dit nog gebruik word, het dit waarskynlik slegs nog te make met vrywillige projekte tot dienslewering, met vrywillige inisiatiewe in die samelewing. In sy omvangryke studie oor die vraag waarom soveel Amerikaners vrywillig betrokke raak by sulke openbare diensaksies, gepubliseer as Acts of compassion. Helping others and helping ourselves, het Robert Wuthnow (1991) egter bevind dat mense selfs dít doen ter wille van hulleself, omdat hulle dit eenvoudig geniet, as interessante afwisseling, of omdat dit hulle goed laat voel oor hulleself. Dit beteken dat nie eens hierdie soort aktiwiteite met die gevoel van geroepe wees deur God gemotiveer word nie.

Hierdie soort tendense kan miskien saamgebundel word in die vraag: Kan mense - gelowiges, Protestantse Christene - vandag nog, in ' $n$ komplekse moderne samelewing en ekonomie, hulle werk, hulle beroepsarbeid, beleef as hulle roeping van Godsweë?

\section{Literatuurverwysings}

Badcock, G D 1998. The Way of Life. A Theology of Christian Vocation. Grand Rapids: William B. Eerdmans Publishing Company.

Bauman, Z 1998. Work, consumerism and the new poor. Buckingham, Philadelphia: Open University Press (Issues In Society).

Botha, J G (ed) 2001. Work as Calling and Worship. Challenging thoughts for our day. Wellington: Lux Verbi. BM.

Forell G W \& Lazareth W H (eds) 1979. Work as praise. Philadelphia: Fortress Press (Justice Books). 
Hare, J E 2001. God's Call. Moral Realism, God's Commands, and Human Autonomy. Grand Rapids: William B. Eerdmans Publishing Company.

Hütter, R 1993. Ecclesial Ethics, The Church's Vocation, and Paraclesis. Pro Ecclesia II/4, 433 - 450.

Lazareth, W H 1979. Work as Praise, in Forell, G W en W H Lazareth (eds). Work as Praise, 43 - 60. Philadelphia: Fortress Press (Justice Books).

Luecke, R H 1979. Unemployment and the Future of Work, in Forell, G W en W H Lazareth (eds). Work as Praise, 7 - 21. Philadelphia: Fortress Press (Justice Books).

Meilaender, G C (ed) 2000. Working. Its Meaning and Its Limits. Notre Dame, Indiana: University of Notre Dame Press.

Pelikan, J 1985. Commandment or Curse? The Paradox of Work in the Judeo-Christian Tradition, in Pelikan, J, Kitagawa, J \& Nasr, S H (eds). Comparative Work Ethics. Judeo-Christian, Islamic, and Eastern, 9 20. Washington: Library of Congress.

Pelikan, J, Kitagawa, J \& Nasr, S H (eds) 1985. Comparative Work Ethics. Judeo-Christian, Islamic, and Eastern, 9 - 20. Washington: Library of Congress.

Placher, W C 1998. What Does My Faith Have To Do With My Job, in Thiemann, R F F \& Placher, W C (eds). Why Are We Here? Everyday Questions and the Christian Life, 130 - 142. Harrisburg, Pennsylvania: Trinity Press International.

Schuurman, D J 1998a. "Abuses and proper uses of vocation: Callings constrictions or forms of love?” NGTT, 39(4), 344 - 354.

-, 1998b. "Abuses and proper uses of vocation: Callings - A cover for injustice or catalyst for transformation?” NGTT, 39(4), 355 - 366.

-, 2001. Can a job be a calling in a sinful society?, in Botha, J G (ed). Work as Calling and Worship. Challenging thoughts for our day, 46 - 70. Wellington: Lux Verbi. BM.

Stevens, R P 1999. The Other Six Days. Vocation, Work, and Ministry in Biblical Perspective. Grand Rapids: William B Eerdmans Publishing Company.

Thiemann, R F F \& Placher, W C (eds) 1998. Why Are We Here? Everyday Questions and the Christian Life, 130 - 142. Harrisburg, Pennsylvania: Trinity Press International.

Volf, M 1991. Work in the Spirit: Toward a Theology of Work. New York: Oxford University Press. 
Wuthnow, R 1991. Acts of compassion: caring for others and helping ourselves. Princeton, New Jork: Princeton University Press. 